\title{
Metaphorical Expression of the Word Anger in the Corpus of Contemporary of American English (COCA)
}

\author{
Dewa Ayu Kartika Sari ${ }^{1 *}$, Ni Ketut Sri Rahayuni \\ ${ }^{[123]}$ English Department - Faculty of Arts - Udayana University \\ ${ }^{1}$ [dewaayukartikasari75@gmail.com] 2[ketutsrirahayuni@gmail.com]
}

*Corresponding Author

\begin{abstract}
Metaphors are used to create poetic impression in poems or poetry. However, linguist disagree this idea and they believe that metaphors are not used for language style of poems or poetry only, but they believe that people also use them in their daily language. This study is entitled Metaphorical Expression of the Word Anger in the Corpus of Contemporary of American English (COCA). The data source was taken from corpus of contemporary American English (COCA) using keyword of anger in Keyword in the Context (KWIC) as the main data. The theories used in this study were theory proposed by Lakoff \& Johnson (1998) to identify the conceptual metaphor, Pragglejaz's MIP (Metaphor Identification Procedure) and Steen's five steps to identify the metaphor in the context. The result shown that all conceptual metaphors were found in this study, such as structural metaphor, orientational metaphor, ontological metaphor and personification.
\end{abstract}

Keywords: Anger, Metaphorical Expression, Conceptual Metaphor.

\begin{abstract}
Abstrak
Metafora digunakan untuk menciptakan kesan puitis pada bahasa sajak atau pantun. Namun, ahli bahasa menentang gagasan ini dan mereka percaya bahwa metafora tidak hanya digunakan untuk bahasa sajak atau pantun, tetapi mereka percaya bahwa orangorang menggunakannya pada bahasa sehari-hari. Penelitian ini berjudul Metaphorical Expression of the Word Anger in the Corpus of Contemporary of American English (COCA). Sumber data diambil dari korpus kontemporari Amerika Inggris (COCA) menggunakan kata kunci anger pada kolom kata kunci dalam konteks sebagai data utama. Teori yang digunakan dalam penelitian ini adalah teori dari Lakoff \& Johnson (1998) untuk mengidentifikasikan metafora konseptual, teori MIP dari Pragglejaz (Metaphor Identification Procedure) dan lima langkah untuk mengidentifikasi metafora dalam kontek oleh Steen. Hasil yang diperoleh menunjukan bahwa semua jenis metafora konseptual ditemukan dalam penelitian ini, seperti metafora structural, metafora orientasional, metafora ontologis dan personifikasi.
\end{abstract}

Kata kunci: Marah, Ekspresi Metafora, Metafora Konseptual.

\section{Background of the study}

In all languages, people know the concept of metaphor. Metaphors are used to create impression of poetic and we usually use them in the language of poems or poetry. However, Lakoff and
Johnson (1980) disagree with the idea. They believe that metaphors exist and are use in our daily lives.

In this study, the metaphorical expressions related to the word anger are interesting to analyse. The data were 
taken from corpus contemporary of American English which means that lots of data can be collected in very limitation time and it uses language naturally, such as spoken, academic, newspaper, magazine, and fiction.

The aims to study metaphor are generally to realize that metaphor is no longer being a part of figurative language, but it has been being a main part of our daily language.

\section{Problems of the study}

Based on the background, the problems of this study can be formulated as follows:

a. What are the linguistic aspects that contribute to the metaphorical expressions?

b. What types of metaphors of word anger found in the Corpus of Contemporary of American English (COCA) based on conceptual metaphors?

\section{Aims of the study}

According to problems, there are two aims that are related to the problems, those are:

a. To identify the linguistic aspects contributing to the metaphorical expressions.

b. To find out the types of metaphors of the word anger found in the Corpus of Contemporary of American English (COCA) based on conceptual metaphors.

\section{Research Method}

In this study research method can be divided into four points, they are data source, method and technique of collecting data, method and technique of analysing data, and method and technique of presenting analysis.

\subsection{Data Source}

The data that were analysed in this study were taken from COCA (Corpus of Contemporary of American English). Corpus is a collection of machinereadable, authentic text, samples and representative of a particular language or language variety.

\subsection{Method and Technique of Collecting Data}

The method used in this study was observation method. Observation method means observing the language use (Sudaryanto: 1993) and this method is not just observing the language use orally, but also the language use in written form (Mahsun: 2005). As the data were taken from COCA, note-taking technique was applied in this study. According to Sudaryanto (1993) notetaking technique means that the data is taken from the data source and filled in the data card based on classification. The data for this study were collected from corpus up to 1,000 data and only 200 data were analysed and randomly chosen.

\subsection{Method and Technique of Analyzing Data}

Firstly, identifying metaphorical expression related to the word anger in COCA. (This step has been done as well in the process of collecting the data). Then, revealing the meaning of the metaphorical expressions that were found using Pragglejaz's MIP (metaphorical Identification Procedure) through Steen's formulas. Afterwards, categorizing and describing the data based on the conceptual metaphor types using the theory proposed by Lakoff and Johnson (1980). Finally, the result of the analysis was presented through descriptive method. 


\subsection{Method and Technique of Presenting Analysis}

In presenting the analysis, the researcher used descriptive method; describing a phenomenon by using words and natural language to answer the problems.

Furthermore, the analysis was divided into three parts as the three conceptual metaphors. First sequence was structural metaphor, orientational metaphor and ontological metaphor. The conceptual metaphors were described by bold small capital letters; the italics represented the metaphorical linguistic expressions that analysed (word anger) and the focus of the analysis in the expressions shown in bold letters.

\section{Analysis}

The analysis is presented through several steps. Firstly, the conceptual metaphor and its metaphorical expressions are presented structurally from the structure metaphor, orientational metaphor, and ontological metaphor with the analysis. Then, the analysis of the word anger in the expression include together with the metaphor analysis.

\subsection{Structural Metaphor}

Data 1: The anger had burned in my soul (\#161)

Step 1:

Anger

Step 2:

$$
\begin{aligned}
& \text { P1 (burn } \left.\text { anger }_{t}\right) \\
& \text { P2 (Mod P1 in) }
\end{aligned}
$$

Step 3:

$$
\begin{array}{ll}
\text { SIM } & \{3 F, 3 a \\
& {[F(\text { Anger })]_{\mathrm{t}}} \\
& [\text { burn }(\mathrm{a})]\}_{\mathrm{s}}
\end{array}
$$

Step 4:

\section{SIM}

$\{$ [damage or destroy something by fire (Anger) $]_{\mathrm{t}}$

[burn (fire)]\}

Step 5:

ANGER > FIRE

Inference: ANGER IS FIRE

ANGER IS FIRE is found as a conceptual metaphor and it belongs to structural metaphor. According to Lakoff \& Johnson (1980) structural metaphors are cases where one concept is metaphorically structured in terms of another. In this case, the concept of FIRE is structured using the concept of ANGER.

\subsection{Orientational Metaphor}

Data 1: Then the action could be even greater and the anger can rise. (\#95)

Step 1:

Anger

Step 2:

$$
\begin{aligned}
& \text { P1 ( } \left.\text { rise }_{\mathrm{s}} \text { anger }_{\mathrm{t}}\right) \\
& \text { P2 (Mod P1 can) }
\end{aligned}
$$

Step 3:

$$
\text { SIM \{3F, \}a }
$$

$[\mathrm{F}(\text { Anger })]_{\mathrm{t}}$

[rise (a) $]\}_{\mathrm{s}}$

Step 4:

SIM

$\{[$ Move from a lower position to a higher one; come or go up (Anger) $]_{t}$ 
[rise (up)]\}

Step 5:

ANGER > UP

Inference: ANGER IS UP

Finding the metaphorical concept ANGER IS UP is unarguable result of the analysis; all people believe and know that anger is in higher position or level. Some of people's acts prove that ANGER IS UP, e.g. when people are in their anger, their intonation will rise up and they will act more than normal. In addition, the word "rise" also has the meaning of "move from a lower position to a higher one; come or go up".

ANGER IS UP was found as a conceptual metaphor and it belongs to orientational metaphor. According to Lakoff \& Johnson (1980) orientational metaphor has to do with spatial orientation, such as up-down, in-out, front-back, on-off, deep-shallow, centralperipheral. In this case, concept of UP is structured using the concept of ANGER.

\subsection{Ontological Metaphor}

Data 1: I watched her anger gushing out like an eruption volcano... (\#119) Step 1:

Anger

Step 2:

P1 (gush out anger $_{\mathrm{t}}$ )

P2 (Mod P1 watch)

Step 3:

$$
\begin{array}{ll}
\text { SIM } & \{3 \mathrm{~F}, 3 \mathrm{a} \\
& {[\mathrm{F}(\text { Anger })]_{\mathrm{t}}} \\
& [\operatorname{gush}(\mathrm{a})]\}_{\mathrm{s}}
\end{array}
$$

Step 4:
$\{[$ (of a liquid) flow out of something in a rapid and plentiful stream. (Anger) $]_{\mathrm{t}}$

substance)]\}

[gush

(explosive

Step 5:

\section{ANGER > EXPLOSIVE SUBSTANCE}

The metaphorical concept ANGER IS AN EXPLOSIVE SUBSTANCE is properly used by the expression above. The verb phrase gush in the text above was categorized as the focus of the metaphorical expression anger. In addition, the basic meaning of gush also supports the metaphorical concept of ANGER IS AN EXPLOSIVE SUBSTANCE. According to Australian Oxford dictionary, gush means (of a liquid) flow out of something in a rapid and plentiful stream.

\section{Conclusions}

Through the word "anger" in the sentences in which the data collected from the corpus was used the object of the analysis, it can be concluded that all of the word "anger" in the sentences were metaphorically used as a metaphorical linguistic expression and together with the phrases as a focus of the analysis in the metaphorical expression. The context of "she must swallow her anger". The word "anger" in this context is found metaphorically used together with its lexical units as the focus of the analysis in the metaphorical expression, such as burn, heating, flash, hear, rise, swallow, gushing out, keep, hold, have, runs, help, rest and come.

Regarding the types of metaphors, the result shown all types of the conceptual metaphors such as structural, orientational and ontological metaphor as well as personification were found in this study. Metaphorical concept appearing in 
the structural metaphor are ANGER IS FIRE, ANGER IS SOUND.

Metaphorical concept appearing in the orientational metaphor is ANGER IS UP. Metaphorical concept appearing in the ontological metaphor are ANGER IS AN OBJECT THAT CAN BE EATEN, ANGER IS AN EXPLOSIVE SUBSTANCE, ANGER IS AN ENTITY, and ANGER IS A MOVING ENTITY. While of the personification, anger is described to have the same characters as a human, ANGER IS HUMAN BEING.

\section{Bibliography}

Lakoff, G. and Johnson, M. (1980). Metaphors We Live By. Chicago, University of Chicago Press

Steen, G. (2007). Finding Metaphor in Discourse: Pragglejaz and Beyond. Vol. V, pp. 9-25.

Sudaryanto. (1993). Metode dan Aneka Teknik Analisis Bahasa. Jakarta: Duta Wacana University Pres 